Materials for energy and environment, next-generation photovoltaics, and green technologies

\title{
Synthesis and properties of Pt/TiN catalyst for low-temperature air purification from carbon monoxide
}

\author{
Evgeny N. Kabachkov ${ }^{a, b} \bowtie$, Evgeny N. Kurkin ${ }^{a, b}$, Nikolay N. Vershinin ${ }^{a}$, \\ Igor L. Balikhin ${ }^{\mathrm{a}, \mathrm{b}}$, Viktor I. Berestenko ${ }^{\mathrm{a}}$, Alexandre V. Michtchenko ${ }^{\mathrm{c}}$, Yury M. Shulga ${ }^{\mathrm{a}, \mathrm{d}}$ \\ ${ }^{a}$ Institute of Problems of Chemical Physics, Russian Academy of Sciences, 1, Academician Semenov Av., \\ Chernogolovka 142432, Russian Federation, \\ ${ }^{\mathrm{b}}$ Chernogolovka Scientific Center, Russian Academy of Sciences, 9, Lesnaya St., \\ Chernogolovka 142432, Russian Federation, \\ ${ }^{\mathrm{c}}$ Instituto Politécnico Nacional, SEPI-ESIME-Zacatenco, Av. IPN S/N, Ed.5, 3-r piso, Ciudad de México, \\ C.P. 07738, México, \\ ${ }^{\mathrm{d}}$ National University of Science and Technology MISIS, 4, Leninsky Pr., Moscow 119049, Russian Federation \\ $\bowtie$ en.kabachkov@gmail.com
}

\begin{abstract}
Catalysts of carbon monoxide oxidation were synthesized by deposition of platinum on titanium nitride (TiN). Two substrates with an average particle size of 18 and $36 \mathrm{~nm}$ were obtained by hydrogen reduction of titanium tetrachloride in a stream of microwave plasma of nitrogen. The surface of the catalysts was studied by X-ray photoelectron spectroscopy (XPS). The data obtained by us in the present work indicate the presence of oxynitride as a transition layer between nitride and oxide. It was found that the $\mathrm{CO}$ oxidation rate on the 9-15 wt. \% Pt loaded TiN catalysts is 120 times higher than that on the platinum black with a specific surface of $30 \mathrm{~m}^{2} \cdot \mathrm{g}^{-1}$. Increase in the reaction rate of CO oxidation on $\mathrm{Pt} / \mathrm{TiN}$ catalysts as compared to platinum black can be associated with both an increase in the concentration of $\mathrm{CO}$ molecules adsorbed and a decrease in the activation energy of the reaction. Catalysts are promising for use in catalytic air purification systems.
\end{abstract}

Keywords: titanium nitride; $\mathrm{Pt} / \mathrm{TiN}$ catalyst; $\mathrm{CO}$ oxidation; X-ray photoelectron spectroscopy; X-ray patterns; transmission electron microscopy.

For citation: Kabachkov EN, Kurkin EN, Vershinin NN, Balikhin IL, Berestenko VI, Michtchenko AV, Shulga YuM. Synthesis and properties of Pt/TiN catalyst for low-temperature air purification from carbon monoxide. Journal of Advanced Materials and Technologies. 2021;6(2):131-143. DOI:10.17277/jamt.2021.02.pp.131-143

\section{Синтез и свойства катализатора Pt/TiN для низкотемпературной очистки воздуха от монооксида углерода}

\author{
Е. Н. Кабачков ${ }^{\text {a,b }}$, Е. Н. Куркин ${ }^{\text {a,b }}$, Н. Н. Вершинин \\ И. Л. Балихин ${ }^{\text {a,b }}$, В. И. Берестенко ${ }^{\mathrm{a}}$, А. В. Мищенко ${ }^{\mathrm{c}}$ Ю. М. Шульга $\mathrm{a}^{\mathrm{a}, \mathrm{d}}$ \\ а Институт проблем химической физики РАН, проспект Академика Семенова, 1, \\ Черноголовка 142432, Российская Федерация, \\ ${ }^{\mathrm{b}}$ Научный иеентр РАН в Черноголовке, ул. Лесная, 9, Черноголовка 142432, Российская Федераџия, \\ ${ }^{\mathrm{c}}$ Национальный Политехнический институт, проспект Национального Политехнического института, б/н, \\ Высшая школа механики и электрики, кампус Сакатенко, здание 5, 07738, Мехико, Мексика, \\ ${ }^{\mathrm{d}}$ Нацииональный исследовательский технологический университет «МИСиС», Ленинский просп. 4, \\ Москва 119049, Российская Федерачия \\ en.kabachkov@gmail.com
}

\begin{abstract}
Аннотация: Катализаторы окисления монооксида углерода синтезированы нанесением платины на плазмохимический нитрид титана (TiN). Порошки TiN со средним размером частиц 18 и 36 нм получены водородным восстановлением тетрахлорида титана в потоке микроволновой азотной плазмы. Поверхность
\end{abstract}


катализаторов исследовалась методом рентгеновской фотоэлектронной спектроскопии (РФЭС). Анализ полученных материалов указывает на наличие оксинитрида как переходного слоя между нитридом и оксидом на поверхности катализаторов. Обнаружено, что скорость окисления CO на катализаторах TiN с добавкой 9-15 мас. \% Pt в 120 раз выше, чем на платиновой саже с удельной поверхностью $30 \mathrm{~m}^{2} / \Gamma$ при комнатной температуре. Увеличение скорости реакции окисления $\mathrm{CO}$ на катализаторах $\mathrm{Pt} / \mathrm{TiN}$ по сравнению с платиновой сажей может быть связано как с увеличением концентрации адсорбированных молекул СО, так и с уменьшением энергии активации реакции. Полученные катализаторы перспективны для использования в системах каталитической очистки воздуха.

Ключевые слова: нитрид титана; катализатор $\mathrm{Pt} / \mathrm{TiN}$; окисление $\mathrm{CO}$; рентгеновская фотоэлектронная спектроскопия; рентгенограммы; просвечивающая электронная микроскопия.

Для цитирования: Kabachkov EN, Kurkin EN, Vershinin NN, Balikhin IL, Berestenko VI, Michtchenko AV, Shulga YuM. Synthesis and properties of Pt/TiN catalyst for low-temperature air purification from carbon monoxide. Journal of Advanced Materials and Technologies. 2021;6(2):131-143. DOI:10.17277/jamt.2021.02.pp.131-143

\section{Introduction}

Investigations and improvements of indoor air purification using heterogeneous photocatalytic oxidation have been devoted to a number of studies [1-6]. $\mathrm{TiO}_{2}$ is commonly used as the photocatalyst in photocatalytic oxidation (PCO) reaction [6-10]. However, not all gases are effectively oxidized by UV irradiation on pure titanium dioxide. In particular, the photocatalytic method of air purification from carbon monoxide gas $(\mathrm{CO})$ on pure titanium dioxide is ineffective. Titanium nitride (TiN) is widely used due to its hardness, high electrical conductivity, corrosion resistance and high melting point [11-13], as well as decorative properties, since its reflection spectrum is very similar to the reflection spectrum of gold [14-17]. Recently, TiN has been used as a catalyst (electrocatalyst) for the oxygen reduction reaction [18-23], as well as a substrate for $\mathrm{M} / \mathrm{TiN}$ catalysts, where $\mathrm{M}$ is a metal [24-31].

Catalytic oxidation of $\mathrm{CO}$ has received considerable attention due to its wide applications in exhaust gas after-treatment, $\mathrm{CO}$ oxidation for proton exchange membrane fuel cells and air purification systems. In the scientific literature, a huge number of works are devoted to the catalytic oxidation of $\mathrm{CO}$ (see, for example, publications [32-40] and references to them). Our attention in this paper is devoted to low-temperature oxidation of $\mathrm{CO}$ in catalytic air purification systems. We note immediately that the term "low-temperature oxidation" is rather a tribute to the tradition, which originates from the work of Haruta et al. [41], who reported that $\mathrm{Au}$ can be a highly active catalyst for the oxidation of $\mathrm{CO}$ at temperatures below $0{ }^{\circ} \mathrm{C}$. In principle, it is desirable to have catalysts in the air purification systems of residential premises that work effectively at room temperature $\left(15-25^{\circ} \mathrm{C}\right)$.

In this report, we present data on the synthesis and the study of the properties of $\mathrm{Pt} / \mathrm{TiN}$ catalysts for efficient room-temperature $\mathrm{CO}$ oxidation. Nano-sized
TiN powder obtained by hydrogen reduction of titanium tetrachloride in a stream of nitrogen plasma was used as a substrate for the preparation of catalysts [42-43]. The study of the properties of catalysts in the oxidation of $\mathrm{CO}$, which is contained in air at low concentrations (less than $100 \mathrm{mg} \cdot \mathrm{m}^{-3}$ ) at $295 \mathrm{~K}$, showed that the $\mathrm{CO}$ oxidation rate on the 9-15 wt. \% Pt loaded TiN catalysts is 120 times higher than that on the platinum black with a specific surface of $30 \mathrm{~m}^{2} \cdot \mathrm{g}^{-1}$.

\section{Materials and methods}

\subsection{Titanium Nitride Synthesis}

Titanium nitride powders were obtained by hydrogen reduction of titanium tetrachloride in a stream of microwave plasma of nitrogen at atmospheric pressure. A mixture of titanium tetrachloride vapors with hydrogen in the required ratio was introduced into a plasma nitrogen stream with a mass-average temperature of about $3000 \mathrm{~K}$, obtained in a plasmatron using a microwave generator with a frequency of $2450 \mathrm{MHz}$ and a maximum useful power of $5 \mathrm{~kW}$.

The average particle size of the obtained powders was controlled by changing the flow rate of $\mathrm{TiCl}_{4}$, which was $0.1 \mathrm{~g} \cdot \mathrm{min}^{-1}$ in obtaining $\mathrm{TiN}$ powder with an average particle size of $18 \mathrm{~nm}$ and $0.25 \mathrm{~g} \cdot \mathrm{min}^{-1}$ in obtaining a powder with a particle size of $36 \mathrm{~nm}$. The plasma-forming nitrogen consumption was $4 \mathrm{~m}^{3} \cdot \mathrm{h}^{-1}$ and hydrogen consumption was $0.5 \mathrm{~m}^{3} \cdot \mathrm{h}^{-1}$ in both cases. Chemical interaction of reagents and condensation of titanium nitride nanoparticles occurred in a tubular reactor with a diameter of $50 \mathrm{~mm}$ and a length of $250 \mathrm{~mm}$, the inner walls of which were lined with quartz. The titanium nitride particles formed in the reactor after cooling the stream were separated from the gas phase by filtration on a bag filter. 
The average particle size of titanium nitride was determined from the results of measuring the specific surface of the powders by low-temperature adsorption of molecular nitrogen (BET method). The particle size $l$ was calculated by the formula $S_{S S}=6 /(l \rho)$, where $S_{S S}$ is the specific surface of the powder, $\rho$ is the specific density of titanium nitride.

\subsection{Catalyst preparation}

To obtain a catalyst, an aqueous solution of $\mathrm{H}_{2} \mathrm{PtCl}_{6} \cdot 6 \mathrm{H}_{2} \mathrm{O}\left(10^{-2} \cdot \mathrm{mol} \cdot \mathrm{L}^{-1}\right)$ was mixed with an aqueous solution of $\mathrm{LiCOOH}\left(0.04-0.1 \mathrm{~mol} \cdot \mathrm{L}^{-1}\right)$ at $20{ }^{\circ} \mathrm{C}$. Then, TiN was ultrasonically dispersed in water at $60{ }^{\circ} \mathrm{C}$, followed by the addition of the required amount of $\mathrm{Pt}$ in the form of an $\mathrm{H}_{2} \mathrm{PtCI}_{6} / \mathrm{LiCOOH}$ mixture. A similar method was described in detail earlier [30].

After the induction period (8-15 min), platinum clusters precipitate on the surface of titanium nitride. Then, after keeping the solution for $24 \mathrm{~h}$ at room temperature, the catalyst was washed with distilled water (5-6 times) from the reaction products.

The washed catalyst was dried at a temperature of $80{ }^{\circ} \mathrm{C}$ for $24 \mathrm{~h}$. Then, partial reduction of platinum clusters was carried out in a $\mathrm{CO}-\mathrm{N}_{2}$ atmosphere (volume fraction of $\mathrm{CO}$ was $10 \%$ ) at a temperature of $90{ }^{\circ} \mathrm{C}$ for $4 \mathrm{~h}$. Two catalysts K18 and K36 with a platinum content of $12 \mathrm{wt} . \%$ were selected as the main objects of study. TiN with a particle size of $(18 \pm 2)$ and $(36 \pm 2) \mathrm{nm}$ was used as a substrate in the K18 and K36 catalysts.

\subsection{Samples characterization}

The surface areas of the TiN samples were obtained from $\mathrm{N}_{2}$ sorption isotherms measured at $77 \mathrm{~K}$ on QUADRASORB SI Analyzer (Quantachrome Instruments). X-ray patterns were recorded using a DRON ADP-2-02 diffractometer using $\mathrm{Cu} \mathrm{K \alpha}$ radiation $(\lambda=0.154056 \mathrm{~nm})$. JEOL JEM 2100 electronic transmission microscope was used to study the structure and composition of $\mathrm{Pt} / \mathrm{TiN}$ catalysts. Analytical scale Acculab ALC-80d4 was used to weigh the reagents and samples.

The XPS spectra were obtained using a Specs PHOIBOS 150 MCD electron spectrometer with an $\mathrm{Mg}$ cathode $(h v=1253.6 \mathrm{eV})$. The vacuum in the spectrometer chamber did not exceed $4 \times 10^{-8} \mathrm{~Pa}$. The spectra were recorded in the constant transmission energy mode ( $40 \mathrm{eV}$ for survey spectra and $10 \mathrm{eV}$ for individual lines). The survey spectrum was recorded in $1.00 \mathrm{eV}$ increments, while the spectra of individual lines were recorded in $0.03 \mathrm{eV}$ increments. Background subtraction was carried out according to the Shirley method [44], and spectra decomposition was performed according to the set of mixed Gaussian/Lorentz peaks in the framework of the Casa XPS 2.3.19 software. For quantitative estimates, we used the table values of specific densities $\left(4.24 \mathrm{~g} \cdot \mathrm{cm}^{-3}\right.$ for $\mathrm{TiO}_{2}$ and $5.44 \mathrm{~g} \cdot \mathrm{cm}^{-3}$ for TiN), as well as the following values of photoelectron escape depths [45]: $\lambda_{1}=\lambda_{\mathrm{Ti} 2 \mathrm{p}}^{\mathrm{TiO}}=3.08 \mathrm{~nm}$, $\lambda_{2}=\lambda_{\mathrm{Ti} 2 \mathrm{p}}^{\mathrm{TiN}}=1.73 \mathrm{~nm}$.

\subsection{Method for the study of catalytic properties}

The kinetics of $\mathrm{CO}$ oxidation in air on the catalyst was studied according to the method described in detail earlier [46]. In brief, the test chamber was purged for $600 \mathrm{~s}$ with a gas mixture of carbon monoxide $\left(150 \mathrm{mg} \cdot \mathrm{m}^{-3}\right)$ and air at a speed of $50 \mathrm{~cm}^{3} \cdot \mathrm{s}^{-1}$. Then, the inlet and outlet valves of the test chamber were closed and the air/gas mixture pump located in the test chamber was turned on, ensuring the circulation of the gas mixture through the catalyst at a speed of $30 \mathrm{~cm}^{3} \cdot \mathrm{s}^{-1}$. After reducing the concentration of $\mathrm{CO}$ due to the catalytic reaction to the level of $100 \mathrm{mg} \cdot \mathrm{m}^{-3}$, a digital stopwatch was turned on and the readings of the sensors were recorded. The test chamber with a volume of $300 \mathrm{~cm}^{3}$ is equipped with NAP-505 CO sensor (Nemoto), MSH optical sensor $\mathrm{CO}_{2}-\mathrm{P} / \mathrm{CO}_{2} / \mathrm{NC} / 5 / \mathrm{V} / \mathrm{P}$ (Dynament), humidity sensor and temperature sensor SHT75 (Sensirion).

\section{Results and Discussion}

\subsection{Titanium Nitride}

Due to the great practical interest, there are many publications in the literature devoted to TiN, including investigation by XPS method [47-54]. However, the interpretation of experimental data obtained by XPS is somewhat different for different authors. This conclusion relates primarily to quantitative estimates, which is connected both with different ways of subtracting the background in the XPS spectra and with the complexity of the object itself.

The fact is that titanium nitride exists as a homogeneous phase over a relatively wide range of compositions and has a tendency to oxidation. The composition and structure of the oxidized layer on the surface of titanium nitride depends on both the preparation method and storage conditions, and on the particle size. 
Fig. 1 shows a survey spectrum of one of the samples of plasma-chemical titanium nitride $(36 \mathrm{~nm})$. We note immediately that the spectra of other samples are not fundamentally different from those given. Table 1 lists the elemental content (in atomic percent) in the layer analyzed by XPS $(2-4 \mathrm{~nm})$. It is seen that the nitride particles are covered with a thick layer of contamination, the origin of which is associated with the high activity of titanium nitride nanoparticles and the conditions of their sufficiently long storage in air. The presence of silicon and sulfur in the sample we associate with the features of the technology for producing titanium nitride.

We analyze the shape of the spectra of Ti2p and N1s. It is known that the Ti2p spectrum of an individual titanium compound is a spin-orbit doublet, which is described by two peaks (Ti2 $p_{1 / 2}$ and Ti2 $p_{3 / 2}$ ) with an intensity ratio of $1: 2$ and a distance between the peaks of $5.7 \mathrm{eV}$ [55].

The experimental spectrum of Ti2p our titanium nitride is well described by 6 peaks or 3 doublets (Fig. 2) corresponding to titanium in nitride (1), oxynitride (2) and oxide (3). The positions and relative intensities of the $T i 2 p_{3 / 2}$ peaks are shown in Table 2.

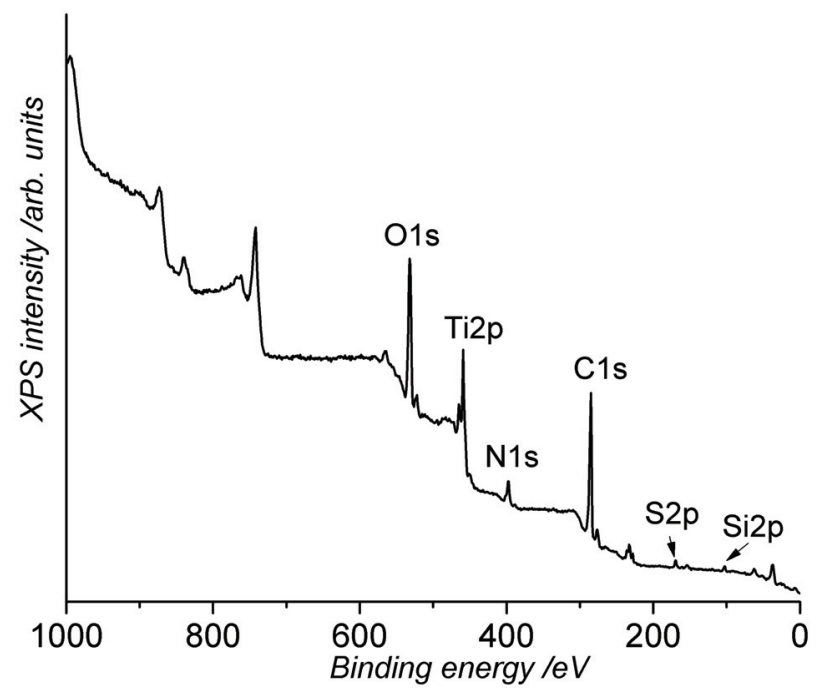

Fig. 1. Survey XPS spectrum of the TiN

Table 1. The XPS composition of the samples under study

\begin{tabular}{lccccccc}
\hline \multirow{2}{*}{ Sample } & \multicolumn{7}{c}{ Composition (at. \%) } \\
& $\mathrm{C}$ & $\mathrm{N}$ & $\mathrm{O}$ & $\mathrm{Pt}$ & $\mathrm{Si}$ & $\mathrm{Ti}$ & $\mathrm{S}$ \\
\hline $\mathrm{TiN}(36 \mathrm{~nm})$ & 58.8 & 6.3 & 23.3 & - & 2.5 & 7.1 & 1.8 \\
$\mathrm{~K} 36$ & 75.9 & 1.8 & 15.4 & 0.4 & 1.2 & 4.9 & $>0.1$ \\
$\mathrm{~K} 18$ & 54.3 & 5.6 & 26.5 & 0.9 & 0.2 & 12.3 & $>0.1$ \\
\hline
\end{tabular}

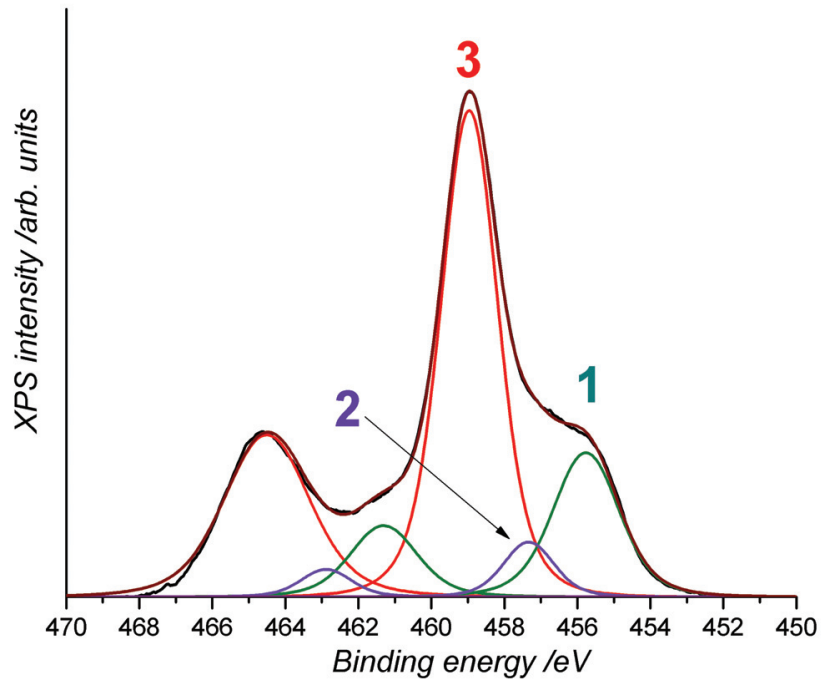

Fig. 2. The Ti2p XPS spectrum of the titanium nitride

Table 2. Peak positions, full width at half-maximum

(FWHM) and intensities of the $T i 2 \mathrm{p}_{3 / 2}$ peaks obtained by decomposing the Ti2p spectra of the samples under study. The designation of the parameter " $d$ " see in the text

\begin{tabular}{cccccc}
\hline Sample & Peak & $E_{b}, \mathrm{eV}$ & FWHM, eV & $I, \%$ & $d, \mathrm{~nm}$ \\
\hline \multirow{4}{*}{ TiN } & 1 & 455.7 & 1.8 & 15.1 & \\
& 2 & 457.3 & 1.7 & 6.9 & 3.7 \\
& 3 & 459.0 & 1.8 & 44.7 & \\
& 1 & 456.1 & 2.0 & 30.3 & \\
$\mathrm{~K} 18$ & 2 & 457.6 & 1.6 & 11.2 & 1.6 \\
& 3 & 459.1 & 1.7 & 25.1 & \\
& 1 & 455.8 & 1.9 & 29.4 & \\
K36 & 2 & 457.4 & 1.7 & 13.1 & 1.5 \\
& 3 & 458.9 & 2.1 & 24.1 & \\
\hline
\end{tabular}

The thickness of the oxide film $d$ can be calculated by a simple formula (see, for example, [34]):

$$
\frac{I_{3}}{I_{1}}=\frac{I_{\mathrm{Ti} 2 \mathrm{p}}^{\mathrm{TiO}}}{I_{\mathrm{Ti} 2 \mathrm{p}}^{\mathrm{TiN}}}=\frac{\sigma_{\mathrm{Ti} 2 \mathrm{p}}^{\mathrm{TiO}_{2}}}{\sigma_{\mathrm{Ti} 2 \mathrm{p}}^{\mathrm{TiN}}} \frac{n_{\mathrm{Ti}}^{\mathrm{TiO}_{2}}}{n_{\mathrm{Ti}}^{\mathrm{TiN}}} \frac{\lambda_{\mathrm{Ti} 2 \mathrm{p}}^{\mathrm{TiO}_{2}}}{\lambda_{\mathrm{Ti} 2 \mathrm{p}}^{\mathrm{TiN}}}\left[\exp \left(d / \lambda_{\mathrm{Ti} 2 \mathrm{p}}^{\mathrm{TiO}_{2}}\right)-1\right],
$$

where $I_{1}$ and $I_{3}$ are the intensity of the peaks given in Table $2, \sigma_{\mathrm{Ti} 2 \mathrm{p}}$ is the ionization cross section of Ti2p level, $\lambda_{\mathrm{Ti} 2 \mathrm{p}}^{\mathrm{TiO}_{2}}$ is the escape depth of Ti2p photoelectrons from the oxide layer on the surface of the nitride.

Formula (1) for nanoparticles gives an overestimated value of $d$ (Table 2), since it is derived 
for a flat infinite sample coated with an oxide film, and does not take into account the contributions to the intensity $I_{3}$ of the oxide film from the side surfaces of the TiN nanoparticles.

The calculation of the intensities $I_{1}$ and $I_{3}$, carried out for a cubic nanoparticle of titanium nitride coated on all sides with an oxide layer $(l$ is the edge of the TiN cube, $d$ is the thickness of the oxide layer on it), assuming that the emission of photoelectrons is recorded in the direction perpendicular to one of the faces of the cube, give the following expressions:

$$
\begin{gathered}
I_{1}=(l-2 d)^{2} \sigma_{\mathrm{Ti} 2 \mathrm{p}}^{\mathrm{TiN}} n_{\mathrm{Ti}}^{\mathrm{TiN}} \lambda_{\mathrm{Ti} 2 \mathrm{p}}^{\mathrm{TiN}} \times \\
\times\left[\exp \left(-d / \lambda_{\mathrm{Ti} 2 \mathrm{p}}^{\mathrm{TiN}}\right)\right]\left[\exp \left(-d / \lambda_{\mathrm{Ti} 2 \mathrm{p}}^{\mathrm{TiO}}\right)\right] \\
I_{3}=\sigma_{\mathrm{Ti} 2 \mathrm{p}}^{\mathrm{TiO}_{2}} n_{\mathrm{Ti}}^{\mathrm{TiO}_{2}} \lambda_{\mathrm{Ti} 2 \mathrm{p}}^{\mathrm{TiO}_{2}}\left[l^{2}-(l-d)^{2} \exp \left(-d / \lambda_{\mathrm{Ti} 2 \mathrm{p}}^{\mathrm{TiO}_{2}}\right)\right] .
\end{gathered}
$$

The estimate of the values of $d$ by Eqs (2) and (3) gives the values of 0.71 and $0.67 \mathrm{~nm}$ for K18 and K36, respectively. These estimates are shown in Table 2 in parentheses. Note that the calculation by formulas (2) and (3), in accordance with the simplifications carried out, gives underestimated values of the oxide layer thickness.

In the spectrum of N1s (Fig. 3), in addition to the main peak related to nitrogen in the mononitride lattice $\left(E_{b}=397.1 \mathrm{eV}\right)$ (see, for example, $\left.[47,55]\right)$, we can distinguish also 2 peaks with $E_{b}=399.2$ and $401.6 \mathrm{eV}$ (Table 3). According to the literature data $[56,57]$, the peak with $E_{b}=399.2 \mathrm{eV}$ can be associated with nitrogen atoms in the lattice of the oxynitride $\mathrm{Ti}(\mathrm{N}, \mathrm{O})$. The peak with $E_{b}=401.6 \mathrm{eV}$ in the literature is often attributed to molecular nitrogen [57-59], which is formed during the oxidation of nitride. However, in the XPS spectra of transition metal (M) complexes with molecular nitrogen $\left(\mathrm{M}-\mathrm{N}_{2}\right)$ the N1s line is split into 2 peaks [60-64]. If we assume that $\mathrm{N}_{2}$ is coordinated in the same way as in a binuclear complex $(\mathrm{M}-\mathrm{N}-\mathrm{N}-\mathrm{M})$, then the value of $E_{b}(\mathrm{~N} 1 \mathrm{~s})$ should be the same as for the exo atom of the mononuclear complex, i.e. below the specified value by at least $1 \mathrm{eV}$. In our opinion, the origin of the peak with $E_{b}=401.6 \mathrm{eV}$ is still questionable. Moreover, many authors do not note this peak in the XPS spectra of the samples of titanium nitride studied by them. In our opinion, the adsorbed NO molecules, nitrogen atoms in the $\mathrm{TiO}_{2}$ lattice and $\mathrm{N} 1 \mathrm{~s}$ photoelectrons from nitride nitrogen, which have lost some of their energy to the excitation of electron transitions from the conduction band to the free band, can contribute to photoemission in the region near $401.6 \mathrm{eV}$.

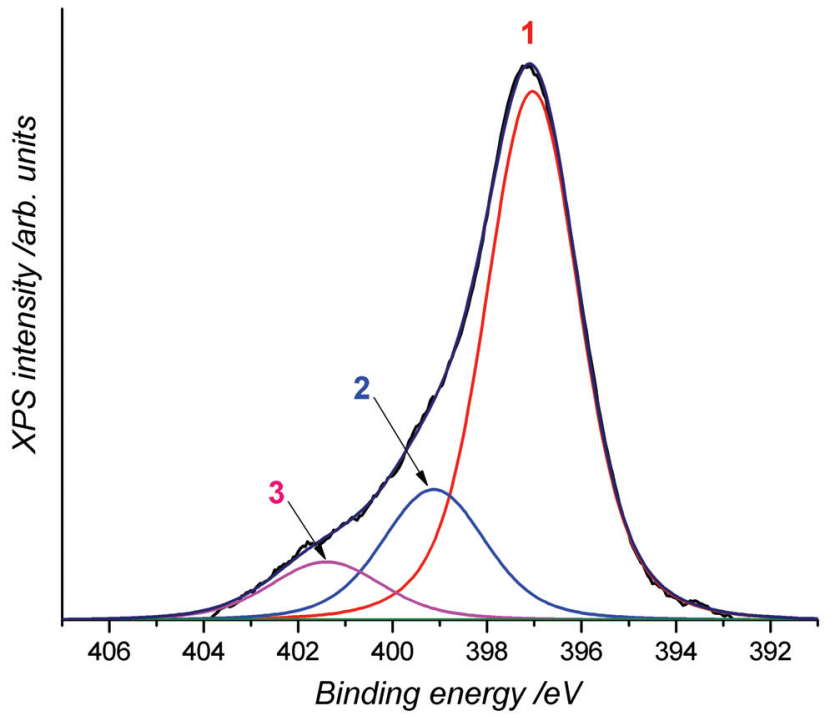

Fig. 3. The N1s XPS spectrum of the titanium nitride

Table 3. Positions, half-widths and intensities of peaks obtained by decomposing the N1s spectra of the initial titanium nitride and catalysts

\begin{tabular}{ccccc}
\hline Sample & Peak & $E_{b}, \mathrm{eV}$ & FWHM, eV & $I, \%$ \\
\hline \multirow{3}{*}{ TiN } & 1 & 397.1 & 2.3 & 71.3 \\
& 2 & 399.2 & 2.5 & 19.3 \\
& 3 & 401.6 & 2.8 & 9.2 \\
\multirow{2}{*}{ K18 } & 1 & 397.1 & 2.0 & 18.1 \\
& 2 & 399.4 & 2.6 & 80.1 \\
& 3 & 401.6 & 1.9 & 1.7 \\
\multirow{2}{*}{ K36 } & 1 & 397.1 & 2.7 & 30.8 \\
& 2 & 399.4 & 2.3 & 61.4 \\
& 3 & 401.6 & 2.7 & 7.7 \\
\hline
\end{tabular}

Thus, the particles of initial titanium nitride are covered with a rather thick film of titanium oxide, which contains nitrogen atoms. Between the nitride and the oxide on its surface is a thin layer of oxynitride.

The stability of bulk samples of titanium nitride in an oxidizing environment is well known. It is clear that the density of titanium atoms in $\mathrm{TiO}_{2}$ is noticeably lower than that in TiN (data on the specific density of $\mathrm{TiO}_{2}$ and $\mathrm{TiN}$ are given above). Therefore, $\mathrm{TiO}_{2}$ on the surface of TiN cannot serve as a protective film preventing diffusion of oxygen to titanium nitride. However, many authors claim that the oxide film on the surface of titanium nitride consists of pure $\mathrm{TiO}_{2}[65,66]$. 
The data obtained by us in the present paper and earlier [67-69] indicate on the presence of oxynitride as a transition layer between nitride and oxide. It is this layer that is the barrier preventing the oxidation of nitride. This data also coincides with the conclusions of Ref. [70].

\subsection{Catalysts}

The contents of elements (in atomic percent) in the near-surface layer of catalysts are presented in Table 1. It can be seen that, as in the initial TiN, a rather thick hydrocarbon film is present on the catalyst surface (high carbon content). The reasons for the appearance of hydrocarbon contamination of the surface are listed above. It can be noted that in the process of preparing catalysts, the $[\mathrm{N} / \mathrm{Ti}]_{\text {at }}$ ratio, calculated from the integrated intensities of the N1s and Ti2p lines, decreases by a factor of 2 .

The results of decomposition of the XPS spectra of Ti2p catalysts are presented in Table 2 . It can be seen that the ratio of $I_{3} / I_{1}$ in catalysts is lower than that in the initial titanium nitride. Consequently, the thickness of the oxide film on the surface of TiN in the catalyst is less than that in the initial TiN. The question arises, how could this happen?

It can be assumed that the reduction of surface titanium oxide also occurred during the reduction of platinum. However, then the second question arises in what form is the reduced part of the titanium oxide film present in the catalyst? Obviously, if the reduction to metal occurred, then contact with air will again lead to oxidation of the metal and formally nothing should change. It seems to us that the increase in the $I_{3} / I_{1}$ ratio is caused by ultrasonic

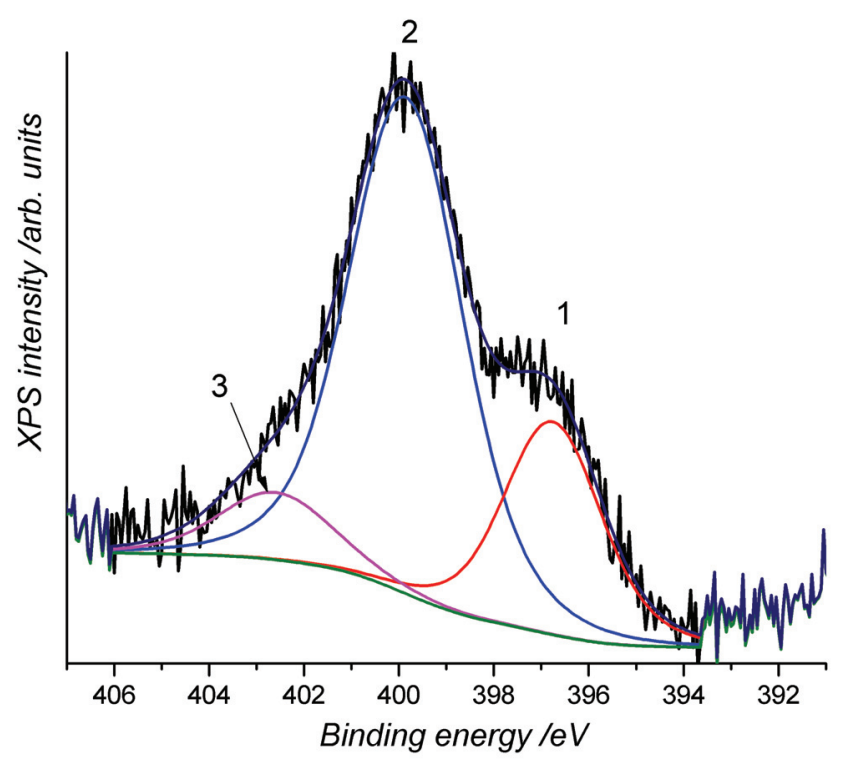

Fig. 4. The N1s XPS spectrum of catalyst K32

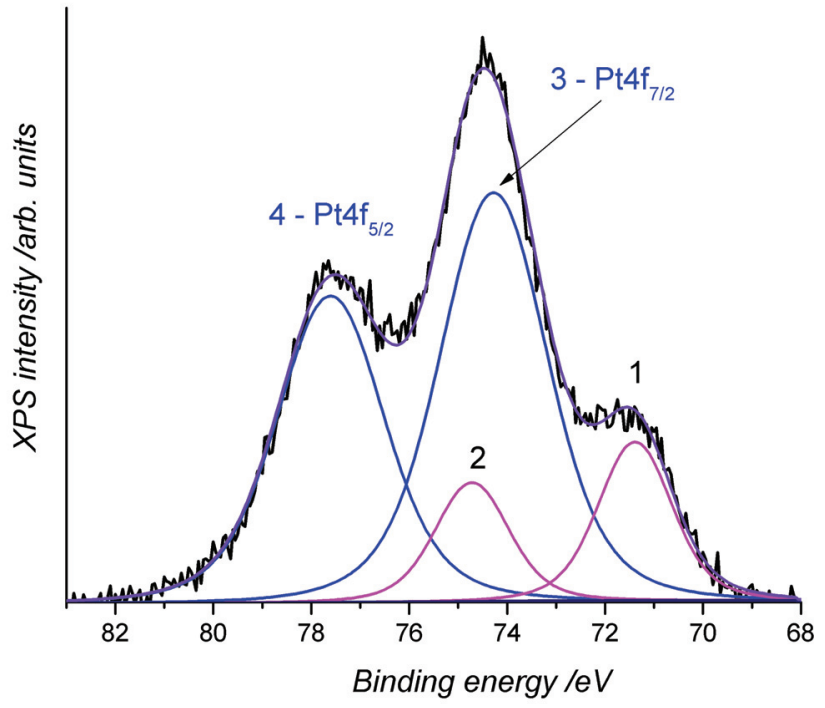

Fig. 5. The Pt4f XPS spectrum of K32 catalyst after treatment with carbon monoxide

mixing and subsequent washing with water during the deposition of platinum. In these operations, the top friable layer of the oxide film can be mechanically destroyed and the separated fine oxide particles were removed from the sample during washing. Analyzing the data of Table 2, it should also be noted that the intensity of peak $2\left(I_{2}\right)$ in the catalysts is higher than that in the initial sample.

On the N1s spectrum (Fig. 4) of the catalyst, the main peak is the peak with $E_{b}=399.2 \mathrm{eV}$. A synchronous increase in the intensities from the oxynitride layer in the N1s and Ti2p spectra means that the influence of this surface layer on the electronic properties of the surface has increased significantly.

The direct contact of platinum with oxinitride cannot be excluded either, since the oxide layer does not have to be continuous. Consequently, the properties of the contact between the catalytically active metal $(\mathrm{Pt})$ and the substrate in the catalyst under study differ significantly from the $\mathrm{Pt} / \mathrm{TiO}_{2}$ contact.

The spectrum of Pt4f is well described by two doublets $\mathrm{Pt} 4 \mathrm{f}_{7 / 2}$ and $\mathrm{Pt}_{4} \mathrm{f}_{5 / 2}$ (Fig. 5), one of which, with $E_{b}\left(\mathrm{Pt}_{4 \mathrm{f}} \mathrm{f}_{7 / 2}\right)=71.4 \mathrm{eV}$, corresponds in its position to metallic platinum, the second (with $\left.E_{b}\left(\mathrm{Pt}_{4} \mathrm{f}_{7 / 2}\right)=74.3 \mathrm{eV}\right)-\mathrm{Pt}^{4+}$ oxide. It should be noted here that the treatment of the catalyst with carbon monoxide does not lead to the complete reduction of platinum.

We also note here that the intensity of the Pt $4 \mathrm{f}$ line is noticeably lower than would be expected from the assumption of a homogeneous distribution of 12 mass. \% platinum (Table 1 ). 


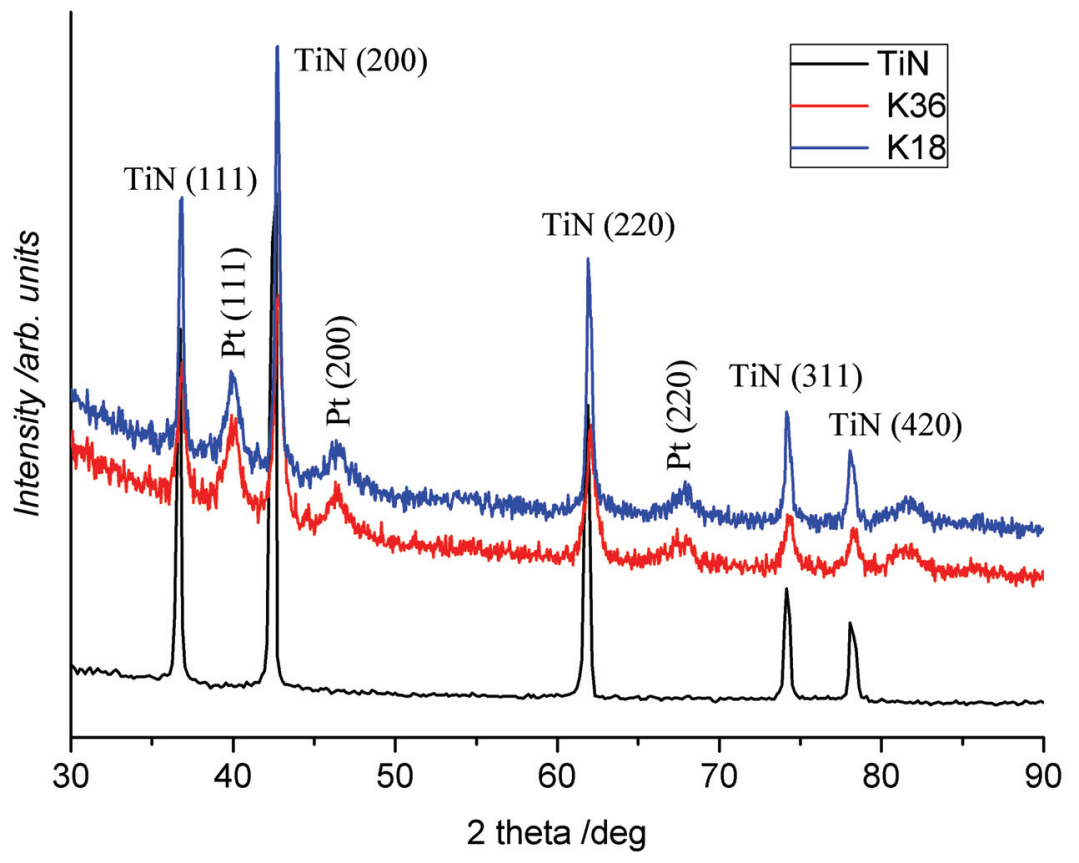

Fig. 6. The X-ray patterns of TiN and K18 and K36 catalysts

If we recalculate the surface composition of catalysts from atomic percent to mass, given in this Table, then, of course, the proportion of platinum will increase, however, for both studied catalysts, it will remain less than 12 mass \%. The reason for this may be that the platinum particles connect several support particles to each other. Such a design naturally suppresses the output of Pt4f photoelectrons. For the system of platinum on $\mathrm{TiO}_{2}$, the phenomenon of strong metal-support interaction (SMSI) is often observed when the metal is covered with an oxide film [71-73].

\subsection{X-ray patterns}

It was found that the titanium nitride obtained by us has a $\mathrm{NaCl}$ type lattice. After deposition of platinum, the lattice parameter of titanium nitride does not change.

Fig. 6 shows the diffraction patterns of catalysts. First, we note that the values of the full-width at half maximum (FWHM) of the reflex Pt (111) in the $\mathrm{X}$-ray patterns of the samples under study are more than those for TiN (111). This means that the sizes of platinum clusters are smaller than the particle sizes of the substrate. Using Scherrer's equation, the width of the $\operatorname{Pt}(111)$ line gives the coherence length $L_{c}=8 \mathrm{~nm}$ for K18. For K36 $L_{c}=12 \mathrm{~nm}$.

Fig. 7 shows a surface image of catalyst K18. It can be seen that platinum clusters with a size of 4-5 $\mathrm{nm}$ are present on the surface of titanium nitride particles. However, the distribution of platinum clusters cannot be called uniform. In the figure, you

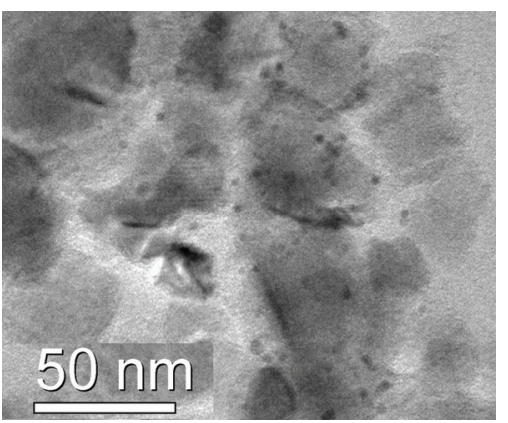

Fig. 7. The TEM image of Pt clusters on the surface of TiN (36 nm)

can see titanium nitride particles on which there are no Pt clusters. The presence of a large number of platinum clusters on some particles of titanium nitride and their absence on other particles of titanium nitride leads to a decrease in the surface concentration of platinum determined by the XPS method.

\subsection{Catalytic properties of Pt/TiN samples}

With a decrease in the $\mathrm{CO}$ concentration in the test chamber, an increase in the $\mathrm{CO}_{2}$ concentration occurs at the same time due to the irreversible oxidation reaction of $\mathrm{CO}$ with air oxygen. As can be seen from Fig. 8 the time dependence of the $\mathrm{CO}$ concentration in the test chamber with a catalyst is described by equation (4):

$$
C_{\mathrm{CO}}(t)=C_{\mathrm{CO}}(0) \mathrm{e}^{-k \cdot t}
$$




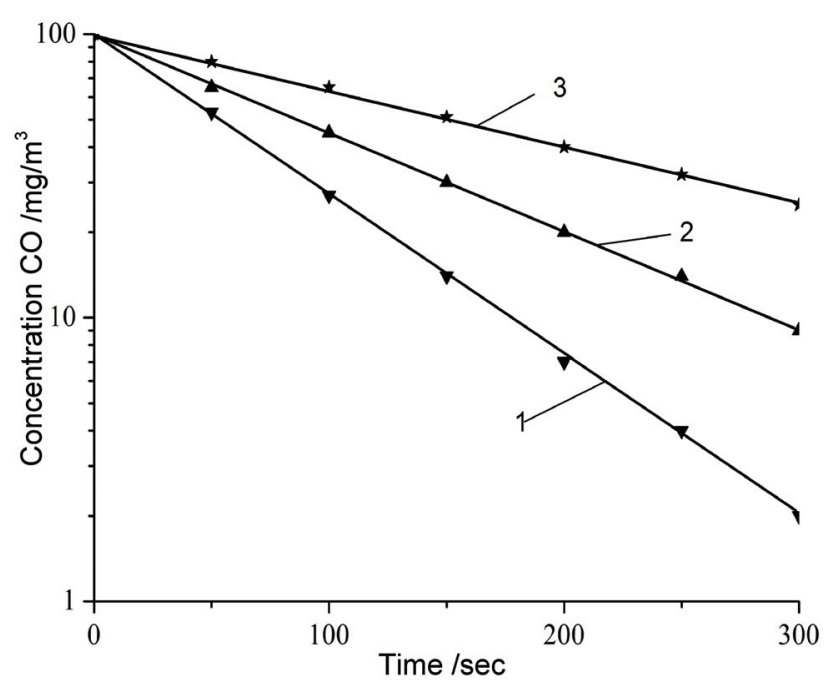

Fig. 8. The kinetics of $\mathrm{CO}$ oxidation

at $T=295 \mathrm{~K}, P=101 \mathrm{kPa}$ and $30 \%$ humidity on $\mathrm{K} 18$ (1), K36 (2) catalysts and on Pt black (3)

(at the same platinum content in the samples)

where $C_{\mathrm{CO}}(t)$ is the measured value of the concentration of $\mathrm{CO}$ in the test chamber, $C_{\mathrm{CO}}(0)$ is the value of the concentration of $\mathrm{CO}$ at the initial (zero) time, $k$ is the reaction rate constant, $t$ is the time.

From the experimental data shown in Fig. 8, it was found that the reaction rate constant on K18 is $(120 \pm 20)$ times higher than that of Pt black with a specific surface of $30 \mathrm{~m}^{2} \cdot \mathrm{g}^{-1}$. It should also be noted that the reaction rate constant on $\mathrm{K} 18$ is $(1.5 \pm 0.1)$ times higher than that on K36.

To study the effect of platinum content on catalytic properties, five samples of a catalyst based on titanium nitride with a particle size of $18 \mathrm{~nm}$ were synthesized and tested (Table 4). The investigation of the $\mathrm{CO}$ oxidation reaction of these samples was carried out according to the procedure described above.

Table 4. The dependence of the catalytic properties of $\mathrm{Pt} / \mathrm{TiN}$ on $\mathrm{Pt}$ content at $T=295 \mathrm{~K}, P=101 \mathrm{kPa}$,

$$
\mathrm{RH}=30 \% \text {. }
$$

\begin{tabular}{cccc}
\hline $\begin{array}{c}\text { No., } \\
\text { sample }\end{array}$ & $V_{x} / V_{12}$ & Sample weight, g & $\begin{array}{c}\text { Pt content, } \\
\text { mass \% }\end{array}$ \\
\hline 1 & 0.90 & 0.050 & 6 \\
2 & 0.95 & 0.033 & 9 \\
3 & 1.00 & 0.025 & 12 \\
4 & 0.95 & 0.020 & 15 \\
5 & 0.70 & 0.012 & 25 \\
\hline
\end{tabular}

When studying the catalytic properties, the mass of the catalyst was changed depending on the composition, leaving the same mass of platinum in each sample equal to $(3 \pm 0.3) \mathrm{mg}$. The reaction rates of $\mathrm{CO}$ oxidation for each sample were determined after processing the experimental data in accordance with equation (3). Then, the ratio of reaction rates $V_{x} / V_{12}$ was determined, where $V_{12}$ is the $\mathrm{CO}$ oxidation rate for a composition containing 12 mass $\%$ of platinum with the maximum rate of oxidation of $\mathrm{CO}$, and $V_{x}$ - the rate of oxidation of $\mathrm{CO}$ for a catalyst containing $x$ mass \% Pt. From the experimental results presented in Table 4 it was found that the oxidation rate of $\mathrm{CO}$ varies little when the platinum content is in interval from 9 to 15 mass $\%$.

To determine the adsorption properties of platinum in the catalysts and in platinum black (90 $\mathrm{mg}$ ), the absorption of $\mathrm{CO}$ from the gas phase was measured. The test chamber was flushed with dry nitrogen at a rate of $50 \mathrm{~cm}^{3} \cdot \mathrm{s}^{-1}$ for $100 \mathrm{~s}$, and then purged with a mixture of $\mathrm{CO}$ and $\mathrm{N}_{2}$ for $5 \mathrm{~s}$ at a rate of $50 \mathrm{~cm}^{3} \cdot \mathrm{s}^{-1}$. Then the inlet and outlet valves were closed and after $10 \mathrm{~min}$ the content of the volume fraction of $\mathrm{CO}$ was analyzed. For the analysis of $\mathrm{CO}$, $3 \mathrm{~cm}^{3}$ samples were taken from the test chamber, and then the sample was injected into a measuring chamber filled with air. The number of CO molecules adsorbed by the Pt surface per unit mass of platinum was calculated by the formula (5):

$$
N_{\mathrm{CO}}=\left(C_{\mathrm{ic}}-C_{\mathrm{fc}}\right) V_{\mathrm{o}} N_{\mathrm{A}} /\left(100 m_{\mathrm{Pt}} V_{\mathrm{M}}\right),
$$

where $C_{\mathrm{ic}}$ is the initial volume fraction of $\mathrm{CO}$ in $\%$, $C_{\mathrm{fc}}$ is the final volume fraction of $\mathrm{CO}$ in $\%, V_{\mathrm{o}}$ is the volume of the test chamber, $N_{\mathrm{A}}$ is the Avogadro number, $m_{\mathrm{Pt}}$ is the mass of platinum in the catalyst in grams, $V_{M}$ is the molar gas volume. The mass of the catalyst was chosen so as to ensure the value of the final concentration in the range from 0.45 to 0.55 of the initial volume fraction of $\mathrm{CO}$ equal to $1 \%$.

After processing the experimental results, it was found that the ratio of $N_{\mathrm{CO}}(\mathrm{Pt} / \mathrm{TiN}) / N_{\mathrm{CO}}(\mathrm{Pt}-$ black $)$ is equal to $(3.8 \pm 0.4)$ for $\mathrm{K} 18$ and to $(2.5 \pm 0.3)$ for K36. The measurements were carried out at $T=295 \mathrm{~K}$ and $P=101 \mathrm{kPa}$.

Thus, an increase in the reaction rate of $\mathrm{CO}$ oxidation on $\mathrm{Pt} / \mathrm{TiN}$ catalysts as compared to platinum black can be associated with both an increase in the concentration of $\mathrm{CO}$ molecules adsorbed and a decrease in the activation energy of the reaction. The reaction rate due to an increase in 
the concentration of $\mathrm{CO}$ molecules on the surface of platinum increases by $(3.8 \pm 0.4)$ times. Therefore, the main reason for the increase in the reaction rate is possible associated with a decrease in the activation energy of the $\mathrm{CO}$ oxidation reaction. From the Arrhenius equation, it follows that with an increase in the reaction rate of $(32 \pm 5)$ times, the calculated value of the decrease in the activation energy will be from 8.1 to $8.5 \mathrm{~kJ} \cdot \mathrm{moL}^{-1}$. The reason for the decrease in the activation energy can be, for example, the formation of oxide layers of platinum on the surface of the Pt cluster.

\subsection{Comparison of the catalytic properties of various nanoscale substrates}

Table 5 shows the results of tests as substrates of nanosized particles such as nanodiamonds (ND) of the SDND (Plasmochem, Germany), $\beta-\mathrm{SiC}$ and TiN, obtained by us by the plasma-chemical method, and $\mathrm{TiO}_{2}$ nanoparticles of the Hombicat (Sachtleben Chemie GmbH, Germany) at the content of Pt in each sample equal to $(12 \pm 1) \mathrm{wt} . \%$. The experimental results were processed based on the equation (4).

The $C_{\mathrm{CO}}(0)$ concentration for all samples is $100 \mathrm{mg} \cdot \mathrm{m}^{-3}$. The characteristics of the substrates used are presented in Table 5 .

Table 5 shows that nanocatalytic additives based on TiN with a particle size of $18 \mathrm{~nm}$ have the maximum rate of the $\mathrm{CO}$ oxidation reaction. We also found that the rate of $\mathrm{CO}$ oxidation at room temperature on this nanocatalytic additives is 120 times higher than that on platinum black with a specific surface area of $30 \mathrm{~m}^{2} \cdot \mathrm{g}^{-1}$.

Table 5. Comparative characteristics of nanoparticles and the ratio $k(x) / k\left(\mathrm{TiO}_{2}\right)$ for a catalyst with a platinum content of $12 \mathrm{wt}$ \%

\begin{tabular}{lccccc}
\hline \multicolumn{1}{c}{ Substrate } & $\mathrm{ND}$ & $\beta-\mathrm{SiC}$ & $\mathrm{TiO}_{2}$ & $\mathrm{TiN}$ & $\mathrm{TiN}$ \\
\hline $\begin{array}{l}\text { Substrate } \\
\text { structure }\end{array}$ & Diamond & Sphalerite & Anatase & $\mathrm{NaCl}$ & $\mathrm{NaCl}$ \\
$\begin{array}{l}\text { Particle size, } \\
\mathrm{nm}\end{array}$ & $5 \pm 1$ & $13 \pm 1$ & $6 \pm 1$ & $36 \pm 4$ & $18 \pm 2$ \\
$\begin{array}{l}\text { Ratio } \\
k(x) / k\left(\mathrm{TiO}_{2}\right)\end{array}$ & $0.7 \pm 0.1$ & $1.0 \pm 0.1$ & 1.0 & $1.0 \pm 0.1$ & $1.5 \pm 0.1$ \\
\hline
\end{tabular}

\section{Conclusions}

New catalysts of carbon monoxide oxidation were synthesized by deposition of platinum on titanium nitride with an average particle size of 18 and $36 \mathrm{~nm}$. It was established that:

1) as a result of catalyst synthesis, the oxide film on the surface of titanium nitride is enriched with nitrogen, and its thickness decreases;

2) surface content of $\mathrm{Pt}$ is less than volume content;

3) treatment of the catalyst with carbon monoxide does not lead to the complete reduction of platinum.

The catalytic properties of $\mathrm{Pt} / \mathrm{TiN}$ samples in the oxidation of $\mathrm{CO}$ at room temperature and low $\mathrm{CO}$ concentrations (less than $100 \mathrm{mg} \cdot \mathrm{m}^{-3}$ ) have been studied. It was found that the CO oxidation constant rate per atom of platinum on the 9-15 wt. \% Pt loaded TiN catalysts is 120 times higher than that on the platinum black with a specific surface of $30 \mathrm{~m}^{2} \cdot \mathrm{g}^{-1}$.

The developed $\mathrm{Pt} / \mathrm{TiN}$ catalyst is promising for further research in order to be used in catalytic and photo-catalytic air purification devices at low $\mathrm{CO}$ concentrations.

\section{Funding}

The study was supported by the Ministry of Science and Higher Education of the Russian Federation for government projects, No. AAAA-A19119061890019-5, and No.AAAA-A19-119032690060-9, and the government program of basic research "For the long-term development and ensuring the competitiveness of society and the state" on the base of the universities (Project No. 0718-2020-0036).

\section{Acknowledgments}

The study used the equipment of the Multi-User Analytical Center of IPCP RAS, and the Chernogolovka Scientific Center RAS. This study was conducted using resources from the Competence Center of National Technology Initiative in IPCP RAS.

\section{Conflict of interests}

The authors declare no conflict of interest.

\section{References}

1. Ren H, Koshy P, Chen W-F, Qi S, Sorrell CC. Photocatalytic materials and technologies for air purification. Journal of Hazardous Materials. 2017;5(325):340-366. DOI:10.1016/j.jhazmat.2016.08.072 
2. $\mathrm{Yu} \mathrm{QL}$, Brouwers HJH. Indoor air purification using heterogeneous photocatalytic oxidation. Part I: experimental study. Applied Catalysis B: Environmental. 2009;92(3-4):454-461. DOI:10.1016/j.apcatb.2009.09.004

3. Li FB, Li XZ, Ao CH, Lee SC, Hou MF. Enhanced photocatalytic degradation of VOCs using $\mathrm{Ln}^{3+}-\mathrm{TiO}_{2}$ catalysts for indoor air purification. Chemosphere. 2005;59(6):787-800. DOI:10.1016/j.chemosphere.2004.11.019

4. Ao $\mathrm{CH}$, Lee SC. Indoor air purification by photocatalyst $\mathrm{TiO}_{2}$ immobilized on an activated carbon filter installed in an air cleaner. Chemical Engineering Science. 2005;60(1):103-109. DOI:10.1016/j.ces.2004.01.073

5. Nonami T, Hase H, Funakoshi K. Apatite-coated titanium dioxide photocatalyst for air purification. Catalysis Today. 2004;96(3):113-118. DOI:10.1016/j.cattod.2004.06.112

6. Boonen E, Beeldens A. Recent photocatalytic applications for air purification in Belgium. Coatings. 2014;4(3):553-573. DOI:10.3390/coatings4030553

7. Zhang N, Yang M-Q, Liu S, Sun Y, Xu Y-J. Waltzing with the versatile platform of graphene to synthesize composite photocatalysts. Chemical Reviews. 2015;115(18):10307-10377. DOI:10.1021/acs.chemrev. $5 \mathrm{~b} 00267$

8. Selmi W, Weber C, Rivière E, Blond N, Mehdi L, Nowak D. Air pollution removal by trees in public green spaces in Strasbourg city, France. Urban Forestry \& Urban Greening. 2016;17:192-201. DOI:10.1016/j.ufug. 2016.04.010

9. Li Z, Ding S, Yu X, Han B, Ou J. Multifunctional cementitious composites modified with nano-titanium dioxide: a review. Composites Part A: Applied Science and Manufacturing. 2018;111:115-137. DOI:10.1016/ j.compositesa.2018.05.019

10. Yu H, Dai W, Qian G, Gong X, Zhou D, Li X, Zhou X. The $\mathrm{NO}_{x}$ degradation performance of nano- $\mathrm{TiO}_{2}$ coating for asphalt pavement. Nanomaterials. 2020;10(5):897(1-16). DOI:10.3390/nano10050897

11. Sundgren J-E, Johansson B-O, Karlsson S-E, Hentzell HTG. Mechanisms of reactive sputtering of titanium nitride and titanium carbide II: Morphology and structure. Thin Solid Films. 1983;105(4):367-384. DOI:10.1016/0040-6090(83)90319-X

12. Sproul WD, Rudnik PJ, Gogol CA. The effect of target power on the nitrogen partial pressure level and hardness of reactively sputtered titanium nitride coatings. Thin Solid Films. 1989;171(1):171-181. DOI:10.1016/ 0040-6090(89)90042-4

13. Cheng H-E, Wen Y-W. Correlation between process parameters, microstructure and hardness of titanium nitride films by chemical vapor deposition. Surface and Coatings Technology. 2004;179(1):103-109. DOI:10.1016/S0257-8972(03)00789-8

14.Zega B, Kornmann M, Amiguet J. Hard decorative TiN coatings by ion plating. Thin Solid Films. 1977;45(3):577-582. DOI:10.1016/0040-6090(77)90249-8

15. Buhl R, Pulker HK, Moll E. TiN coatings on steel. Thin Solid Films. 1981;80(1):265-270. DOI:10.1016/00406090(81)90233-9
16. Mumtaz A, Class WH. Color of titanium nitride prepared by reactive dc magnetron sputtering. Journal of Vacuum Science and Technology. 1982;20:345-348. DOI: $10.1116 / 1.571461$

17. Niyomsoan S, Grant W, Olson DL, Mishra B. Variation of color in titanium and zirconium nitride decorative thin films. Thin Solid Films. 2002; 415(1-2):187-194. DOI:10.1016/S0040-6090(02)00530-8

18. Youn DH, Bae G, Han S, Kim JY, Jang J-W, Park H, Choi SH, Lee JS. A highly efficient transition metal nitride-based electrocatalyst for oxygen reduction reaction: TiN on a CNT-graphene hybrid support. Journal of Materials Chemistry A. 2013;1(27):8007-8015. DOI:10.1039/C3TA11135K

19. Nan H, Dang D, Tian XL. Structural engineering of robust titanium nitride as effective platinum support for the oxygen reduction reaction. Journal of Materials Chemistry A. 2018;6(14):6065-6073. DOI:10.1039/ C8TA00326B

20. Pan Z, Xiao Y, Fu Z, Zhan G, Wu S, Xiao C, $\mathrm{Hu} \mathrm{G}$, Wei $\mathrm{Z}$. Hollow and porous titanium nitride nanotubes as high-performance catalyst supports for oxygen reduction reaction. Journal of Materials Chemistry $A$. 2014;2(34):13966-13975. DOI:10.1039/C4TA02402H

21. Dong Y, Wu Y, Liu M, Li J. Electrocatalysis on shape-controlled titanium nitride nanocrystals for the oxygen reduction reaction. ChemSusChem. 2013;6(10):2016-2021. DOI:10.1002/cssc.201300331

22. Liu M, Dong Y, Wu Y, Feng H, Li J. Titanium nitride nanocrystals on nitrogen-doped graphene as an efficient electrocatalyst for oxygen reduction reaction. Chemistry. 2013;19(44):14781-14786. DOI:10.1002/ chem.201302425

23. Shin H, Kim H-I, Chung DY, Yoo JM, Weon S, Choi W, Sung Y-E. Scaffold-like titanium nitride nanotubes with a highly conductive porous architecture as a nanoparticle catalyst support for oxygen reduction. ACS Catalysis. 2016;6(6):3914-3920. DOI:10.1021/ acscatal.6b00384

24. Yang S, Chung DY, Tak Y-J, Kim J, Han H, Yu J-S, Soon A, Sung Y-E, Lee H. Electronic structure modification of platinum on titanium nitride resulting in enhanced catalytic activity and durability for oxygen reduction and formic acid oxidation. Applied Catalysis B: Environmental. 2015;174-175:35-42. DOI:10.1016/ j.apcatb.2015.02.033

25.Zhang J, Ma L, Gan M, Fu S, Zhao Y. TiN@, nitrogen-doped carbon supported Pt nanoparticles as highperformance anode catalyst for methanol electrooxidation. Journal of Power Sources. 2016;324:199-207. DOI: 10.1016/j.jpowsour.2016.05.083

26. Lee J-M, Han S-B, Song Y-J, Kim J-Y, Roh B, Hwang I, Choi W, Park K-W. Methanol electrooxidation of Pt catalyst on titanium nitride nanostructured support. Applied Catalysis A: General. 2010;375(1):149-55. DOI: 10.1016/j.apcata.2009.12.037

27. Yang M, Cui Z, DiSalvo FJ. Mesoporous titanium nitride supported $\mathrm{Pt}$ nanoparticles as high performance catalysts for methanol electrooxidation. Physical 
Chemistry Chemical Physics. 2013;15(4):1088-1092. DOI: $10.1039 / \mathrm{c} 2 \mathrm{cp} 44215 \mathrm{a}$

28. Thotiyl MMO, Sampath S. Electrochemical oxidation of ethanol in acid media on titanium nitride supported fuel cell catalysts. Electrochimica Acta. 2011;56(10):3549-3554. DOI:10.1016/j.electacta.2010.12.091

29. Xiao Y, Fu Z, Zhan G, Pan Z, Xiao C, Wu S, Chen $\mathrm{C}, \mathrm{Hu} \mathrm{G}$, Wei Z. Increasing Pt methanol oxidation reaction activity and durability with a titanium molybdenum nitride catalyst support. Journal of Power Sources. 2015;273:33-40. DOI:10.1016/j.jpowsour. 2014.09.057

30. Ottakam Thotiyl MM, Ravikumar T, Sampath S. Platinum particles supported on titanium nitride: an efficient electrode material for the oxidation of methanol in alkaline media. Journal of Materials Chemistry. 2010;20(47):10643-10651. DOI:10.1039/C0JM01600D

31. Centeno MÁ, Carrizosa I, Odriozola JA. Deposition-precipitation method to obtain supported gold catalysts: dependence of the acid-base properties of the support exemplified in the system $\mathrm{TiO}_{2}-\mathrm{TiO}_{x} \mathrm{~N}_{y}-\mathrm{TiN}$. Applied Catalysis A: General. 2003;246(2):365-372. DOI: 10.1016/s0926-860x(03)00058-9

32. Heiz U, Sanchez A, Abbet S, Schneider W-D. Catalytic oxidation of carbon monoxide on monodispersed platinum clusters: each atom counts. Journal of the American Chemical Society. 1999;121(13):3214-3217. DOI:10.1021/ja9836161

33. Lopez N, Norskov JK. Catalytic CO oxidation by a gold nanoparticle: a density functional study. Journal of the American Chemical Society. 2002;124(38):11262-11263. DOI:10.1021/ja026998a

34. Min BK, Friend CM. Heterogeneous gold-based catalysis for green chemistry: low-temperature $\mathrm{CO}$ oxidation and propene oxidation. Chemical Reviews. 2007;107(6):2709-2724. DOI:10.1021/cr050954d

35. Di L, Xu W, Zhan Z, Zhang X. Synthesis of alumina supported $\mathrm{Pd}-\mathrm{Cu}$ alloy nanoparticles for $\mathrm{CO}$ oxidation via a fast and facile method. RSC Advances. 2015;5:71854-71858. DOI:10.1039/c5ra13813b

36. Akita T, Maeda Y, Kohyama M. Low-temperature $\mathrm{CO}$ oxidation properties and TEM/STEM observation of $\mathrm{Au} / \gamma-\mathrm{Fe}_{2} \mathrm{O}_{3}$ catalysts. Journal of Catalysis. 2015;324:127132. DOI:10.1016/j.jcat.2015.02.006

37. He J-Q, Chen D-Y, Li N-J, Xu Q-F, Li H, He J-H, $\mathrm{Lu}$ J-M. Hollow mesoporous $\mathrm{Co}_{3} \mathrm{O}_{4}-\mathrm{CeO}_{2}$ composite nanotubes with open ends for efficient catalytic $\mathrm{CO}$ oxidation. ChemSusChem. 2019;12(5):1084-1090. DOI: 10.1002/cssc. 201802501

38. Wang Y, Yang D, Li S, Zhang L, Zheng G, Guo L. Layered copper manganese oxide for the efficient catalytic CO and VOCs oxidation. Chemical Engineering Journal. 2019;357:258-268. DOI:10.1016/j.cej. 2018.09.156

39. Taira K, Einaga $\mathrm{H}$. The Effect of $\mathrm{SO}_{2}$ and $\mathrm{H}_{2} \mathrm{O}$ on the interaction between $\mathrm{Pt}$ and $\mathrm{TiO}_{2}$ (P-25) during catalytic CO oxidation. Catalysis Letters. 2019;149(4):965-973. DOI:10.1007/s10562-019-02672-3
40. Bikaljevic D, Rameshan R, Köpfle N, Götsch T, Mühlegger E, Schlögl R, Penner S, Memmel N, Klötzer B. Structural and kinetic aspects of $\mathrm{CO}$ oxidation on $\mathrm{ZnO}_{x}$-modified $\mathrm{Cu}$ surfaces. Applied Catalysis A: General. 2019;572:151-157. DOI:10.1016/j.apcata.2018.12.032

41. Haruta M, Yamada N, Kobayashi T, Iijima S. Gold catalysts prepared by coprecipitation for lowtemperature oxidation of hydrogen and of carbon monoxide. Journal of Catalysis. 1989;115(2):301-309. DOI:10.1016/0021-9517(89)90034-1

42. Troitsky VN, Gurov SV, Berestenko VI. Peculiarities of production of highly dispersed powders of nitrides of $\mathrm{iV}$ group metals by reduction of chloride in low temperature plasma. High Energy Chemistry. 1979;13:267-272.

43. Balikhin IL, Berestenko VI, Domashnev IA, Kurkin EN, Troitskij VN. Installation and method for production of nanodispersed powders in microwave plasma. Russian Federation patent 2,252,817. 15 October 2005.

44. Castle JE. Practical surface analysis by Auger and X-ray photoelectron spectroscopy. Surface and Interface Analysis. 1984;6:302-302. DOI:10.1002/sia.740060611

45. Seah MP, Dench WA. Quantitative electron spectroscopy of surfaces: A standard data base for electron inelastic mean free paths in solids. Surface and Interface Analysis. 1979;1:2-11. DOI:10.1002/sia.740010103

46. Vershinin NN, Bakaev VA, Berestenko VI, Efimov ON, Kurkin EN, Kabachkov EN. Synthesis and properties of a platinum catalyst supported on plasma chemical silicon carbide. High Energy Chemistry. 2017;51(1):46-50. DOI:10.1134/S0018143916060199

47. Shulga YM, Troitskii VN, Aivazov MI, Borodko YG. X-ray photo-electron spectra of the mononitrides of Sc, Ti, V and Cr. Russian Journal of Inorganic Chemistry. 1976;21(10):2621-2624.

48. Johansson LI, Stefan PM, Shek ML, Nørlund CA. Valence-band structure of TiC and TiN. Physical Review B. 1980;22:1032-1037. DOI:10.1103/physrevb.22.1032

49. Porte L, Roux L, Hanus J. Vacancy effects in the X-ray photoelectron spectra of $\mathrm{TiN}_{x}$. Physical Review $B$. 1983;28:3214-3224. DOI:10.1103/physrevb.28.3214

50. Bertóti I. Characterization of nitride coatings by XPS. Surface and Coatings Technology. 2002;151-152:194203. DOI:10.1016/s0257-8972(01)01619-X

51. Gall D, Haasch RT, Finnegan N, Lee T-Y, Shin C-S, Sammann E, Greene JE, Petrov I. In situ X-ray photoelectron, ultraviolet photoelectron, and auger electron spectroscopy spectra from first-row transition-metal nitrides: ScN, TiN, VN, and CrN. Surface Science Spectra. 2000;7(3):167-168. DOI:10.1116/1.1360984

52. Bertóti I. Characterization of nitride coatings by XPS. Surface and Coatings Technology. 2002;151152:194-203. DOI:10.1016/s0257-8972(01)01619-X

53. Glaser A, Surnev S, Netzer FP, Fateh N, Fontalvo GA, Mitterer C. Oxidation of vanadium nitride and titanium nitride coatings. Surface Science. 2007;601(4):1153-1159. DOI:10.1016/j.susc.2006.12.010 
54. Patscheider J, Hellgren N, Haasch RT, Petrov I, Greene JE. Electronic structure of the $\mathrm{SiN}_{x} / \mathrm{TiN}$ interface: A model system for superhard nanocomposites. Physical Review B. 2011;83:125124(1-7) DOI:10.1103/physrevb. 83.125124

55. Moulder JF, Stickle WF, Sobol PE, Bomben KD. Handbook of X-ray Photoelectron Spectroscopy. Minnesota: Perkin-Elmer Corp., Physical Electronics; 1995. $261 \mathrm{p}$.

56. Jiang N, Zhang HJ, Bao SN, Shen YG, Zhou ZF. XPS study for reactively sputtered titanium nitride thin films deposited under different substrate bias Physica B: Condensed Matter. 2004;352(1-4):118-126. DOI:10.1016/ j.physb.2004.07.001

57. Milov I, Strehblow H-H, Navinek B, MetikoHukovi M. Electrochemical and thermal oxidation of TiN coatings studied by XPS. Surface and Interface Analysis. 1995;23(7-8):529-539. DOI:10.1002/sia.740230713

58. Saha NC, Tompkins HG. Titanium nitride oxidation chemistry: An X-ray photoelectron spectroscopy study. Journal of Applied Physics. 1992;72(7):3072-3079. DOI:10.1063/1.351465

59. Esaka F, Furuya K, Shimada H, Imamura M, Matsubayashi N, Sato H, Nishijima A, Kawana A, Ichimura $\mathrm{H}$, Kikuchi T. Comparison of surface oxidation of titanium nitride and chromium nitride films studied by X-ray absorption and photoelectron Journal of Vacuum Science \& Technology A: Vacuum, Surfaces, and Films. 1997;15:2521-2528. DOI:10.1116/1.580764

60. Leigh GJ, Murrell JN, Bremser W, Proctor WG. On the state of dinitrogen bound to rhenium. Journal of the Chemical Society D: Chemical Communications. 1970;24:1661. DOI:10.1039/c29700001661

61. Leigh GJ, Bremser W. X-ray photoelectron spectroscopic studies of tertiary phosphine complexes of heavy transition metals. Journal of the Chemical Society, Dalton Transactions. 1972;12:1216-1219. DOI:10.1039/ dt9720001216

62. Nefedov VI, Lenenko VS, Shur VB, Vol'pin ME, Salyn JE, Porai-Koshits MA. Molecular nitrogen as a ligand. A study of dinitrogen complexes of transition metals, diazocompounds, and azides by X-ray photoelectron spectroscopy. Inorganica Chimica Acta. 1973;7:499-502. DOI:10.1016/s0020-1693(00)94872-2

63. Chatt J, Elson CM, Hooper NE, Jeffery LG. On the charge distribution in complexes. Journal of the
Chemical Society, Dalton Transactions. 1975;22:23922401. DOI:10.1039/dt9750002392

64. Brant P, Feltham RD. X-ray photoelectron spectra of molybdenum dinitrogen complexes and their derivatives. Journal of the Less Common Metals. 1977;54(1):81-87. DOI:10.1016/0022-5088(77)90128-x

65. Heide N, Schultze JW. Corrosion stability of TiN prepared by ion implantation and PVD. Nuclear Instruments and Methods in Physics Research Section B: Beam Interactions with Materials and Atoms. 1993;80-81:467-471. DOI:10.1016/0168-583x(93)96162-6

66. François JC, Massiani Y, Gravier P, Grimblot J, Gengembre L. Characterization and optical properties of thin films formed on TiN coatings during electrochemical treatments Thin Solid Films. 1993;223(2):223-229. DOI:10.1016/0040-6090(93)90525-t

67. Shulga YM, Troitsky VN. Study of the surface of finely divided titanium nitride by X-ray photoelectron spectroscopy. Powder Metallurgy and Metal Ceramics. 1979;18(10):681-684 DOI:10.1007/BF00797433

68. Shulga YM, Klyashchitsky GY, Rubtsov VI, Kurkin EN, Troitskiy VN. Investigation of ultra-fine powders from Nb-N system by methods of XPs- and AEs. Physics, Chemistry and Mechanics of Surfaces. 1991;9:67.

69. Rubtsov VI, Shulga YM, Troitski VN, Kurkin EN, Budanov AA. Electron spectroscopy study of $\mathrm{Nb}_{1-x} \mathrm{Ti}_{x} \mathrm{~N}_{1-y} \mathrm{C}_{y}$ ultrafine powders. Physics of LowDimensional Structures. 1995;12:287.

70. Massiani Y, Medjahed A, Gravier P, Argème L, Fedrizzi L. Electrochemical study of titanium nitride films obtained by reactive sputtering. Thin Solid Films. 1990;191(2):305-316. DOI:10.1016/0040-6090(90)90382-n

71. Tauster SJ. Strong metal-support interactions. Accounts of Chemical Research. 1987;20(11):389-394. DOI:10.1021/ar00143a001

72. Pan C-J, Tsai M-C, Su W-N, Rick J, Akalework NG, Agegnehu AK, Cheng S-Y, Hwang B-J. Tuning/exploiting strong metal-support interaction (SMSI) in heterogeneous catalysis. Journal of the Taiwan Institute of Chemical Engineers. 2017;74:154-186. DOI:10.1016/j.jtice.2017.02.012.

73. Han B, Guo Y, Huang Y, Xi W, Xu J, Luo J, Qi H, Ren Y, Liu X, Qiao B, Zhang T. Strong metal-support interactions between $\mathrm{Pt}$ single atoms and $\mathrm{TiO}_{2}$. Angewandte Chemie. 2020;59(29):11824-11829. DOI:10.1002/anie.202003208

\section{Информация об авторах / Information about the authors}

Кабачков Евгений Николаевич, научный сотрудник, Институт проблем химической физики РАН; Научный центр РАН в Черноголовке, Черноголовка, Московская область, Российская Федерация; ORCID 0000-0003-3790-935X; e-mail: En.kabachkov@gmail.com
Evgeny N. Kabachkov, Researcher, Institute of the Problems of Chemical Physics of the Russian Academy of Sciences; Chernogolovka Scientific Center, Chernogolovka, Moscow Region, Russian Federation; ORCID 0000-0003-3790-935X; e-mail: En.kabachkov@gmail.com 
Куркин Евгений Николаевич, кандидат химических наук, ведущий научный сотрудник, Институт проблем химической физики РАН; Научный центр РАН в Черноголовке, Черноголовка, Московская область, Российская Федерация; ORCID 0000-0001-8372-3092; e-mail: Kurkin@icp.ac.ru

Вершинин Николай Николаевич, кандидат химических наук, старший научный сотрудник, Институт проблем химической физики РАН, Черноголовка, Московская область, Российская Федерация; AuthorID (Scopus) 7003927801; e-mail: vernik@icp.ac.ru

Балихин Игорь Львович, кандидат химических наук, старший научный сотрудник, Институт проблем химической физики РАН; Научный центр РАН в Черноголовке, Черноголовка, Московская область, Российская Федерация; AuthorID (Scopus) 6506779122; e-mail: bil@icp.ac.ru

Берестенко Виктор Иванович, кандидат химических наук, старший научный сотрудник, Институт проблем химической физики РАН, Черноголовка, Московская область, Российская Федерация; AuthorID (Scopus) 6506792982; e-mail: vib@icp.ac.ru

Мищенко Александр Владимирович, кандидат физико-математических наук, профессор, Национальный политехнический институт Мексики, Мехико, Мексика; ORCID 0000-0002-3799-581X; e-mail: almitchen@gmail.com

Шульга Юрий Макарович, кандидат химических наук, ведущий научный сотрудник, Институт проблем химической физики РАН, Черноголовка, Московская область, Российская Федерация; Национальный исследовательский технологический университет «МИСиС», Москва, Российская Федерация; ORCID 0000-0001-8020-4465; e-mail: yshulga@gmail.com
Evgeny N. Kurkin, Cand. Sc. (Chemistry), Leading Researcher, Institute of the Problems of Chemical Physics of the Russian Academy of Sciences; Chernogolovka Scientific Center, Chernogolovka, Moscow Region, Russian Federation; ORCID 00000001-8372-3092; e-mail: Kurkin@icp.ac.ru

Nikolay N. Vershinin, Cand. Sc. (Chemistry), Senior Researcher, Institute of the Problems of Chemical Physics of the Russian Academy of Sciences, Chernogolovka, Moscow Region, Russian Federation; AuthorID (Scopus) 7003927801; e-mail: vernik@ icp.ac.ru

Igor L. Balikhin, Cand. Sc. (Chemistry), Senior Researcher, Institute of the Problems of Chemical Physics of the Russian Academy of Sciences; Chernogolovka Scientific Center, Chernogolovka, Moscow Region, Russian Federation; AuthorID (Scopus) 6506779122; e-mail: bil@icp.ac.ru

Viktor I. Berestenko, Cand. Sc. (Chemistry), Senior Researcher, Institute of the Problems of Chemical Physics of the Russian Academy of Sciences, Chernogolovka, Moscow Region, Russian Federation; AuthorID (Scopus) 6506792982; e-mail: vib@icp.ac.ru

Alexandre V. Michtchenko, Cand. Sc. (Physics and Mathematics), Professor, Instituto Politécnico Nacional, SEPI-ESIME-Zacatenco, Av. IPN S/N, Ed.5, 3-r piso, Ciudad de México, C.P. 07738, México; ORCID 00000002-3799-581X; e-mail: almitchen@gmail.com

Yury M. Shulga, Cand. Sc. (Chemistry), Leading Researcher, Institute of the Problems of Chemical Physics of the Russian Academy of Sciences, Chernogolovka, Moscow Region, Russian Federation; National University of Science and Technology MISIS, Moscow, Russian Federation; ORCID 0000-0001-80204465; e-mail: yshulga@gmail.com 